\title{
EKSISTENSI MANUSIA DALAM FILM "AISYAH BIARKAN KAMI BERSAUDARA” KARYA HERWIN NOVIANTO
}

\section{HUMAN EXISTENCE IN THE FILMS “AISYAH BIARKAN KAMI BERSAUDARA” BY HERWIN NOVIANTO}

\author{
Susiati \\ Universitas Iqra Buru \\ Jalan Prof. Dr. H. A.R. Basalamah No. 20, Namlea, Buru \\ Telepon (0913) 21909, Pos-el: susiatiuniqbu@gmail.com
}

\begin{abstract}
Abstrak
Penelitian ini bertujuan mendeskripsikan eksistensi manusia dalam film "Aisyah Biarkan Kami Bersaudara" karya Herwin Novianto. Penelitian ini merupakan penelitian kualitatif. Data dikumpulkan menggunakan metode audio visual, yakni dengan melihat dan mendengar suatu objek dari gambar dan suara. Sementara itu, teknik pengumpulan data menggunakan teknik simak dan catat. Data dianalisis secara deskriptif sesuai dengan teori konsep eksistensi manusia Koeswara yang meliputi empat jenis, yakni kebersamaan dan cinta, pertentangan, keterasingan dan kesepian, serta kematian. Hasil penelitian menunjukkan bahwa konsep eksistensi manusia dalam film "Aisyah Biarkan Kami Bersaudara" karya Herwin Novianto ada tiga, yakni (1) konsep kebersamaan dan cinta, meliputi keakraban, saling membantu/kerja sama, menasehati, rasa saling menghormati dan menghargai, perhatian, tanggung jawab, keterbukaan, rasa iba, tepa salira, berkeyakinan, serta berkelakar; (2) konsep pertentangan, meliputi ketidaksetujuan, ketidaksepahaman, rasa tidak menghargai, ketidakterimaan, ketidakpercayaan, dan kebencian; (3) konsep keterasingan dan kesepian, meliputi kesedihan, kegelisahan, kejengkelan, kekhawatiran, ketakutan, dan kebohongan.
\end{abstract}

Kata kunci: eksistensi manusia, film, Aisyah Biarkan Kami Bersaudara

\begin{abstract}
This study aims to describe human existence in the film "Aisyah Biarkan Kami Bersaudara" by Herwin Novianto. This research is a qualitative research. Data is collected using the audio visual method, namely by seeing and hearing an object from images and sounds. Meanwhile, data collection techniques use the refer and note technique. Data were analyzed descriptively in accordance with Koeswara's human existence concept theory which included four types, namely togetherness and love, opposition, alienation and loneliness, and death. The results showed that the concept of human existence in the film "Aisyah Biarkan Kami Bersaudara" by Herwin Novianto have three, namely (1) the concept of togetherness and love, including intimacy, mutual assistance/cooperation, advising, mutual respect and respect, attention, responsibility, openness, compassion, tepa salira, belief, and joke; (2) the concept of conflict, including disagreement, disagreement, disrespect, acceptability, distrust, and hatred; (3) the concept of alienation and loneliness, including sadness, anxiety, aggravation, worry, fear, and lies.
\end{abstract}

Keywords: human existence, film, "Aisyah Biarkan Kami Bersaudara”

\section{Pendahuluan}

Sastra merupakan bagian dari manifestasi keadaan sosial kemasyarakatan. Karya sastra adalah suatu wujud yang mencerminkan perilaku, kejadian, keunikan, keberagaman masyarakat dalam setiap kurun waktu tertentu. Segala wujud cerminan masyarakat dapat digubah dalam sebuah sketsa karya sastra dengan tidak menghilangkan nilai rasa asli dari kenyataan yang terjadi dalam masyarakat.

Gramatika, Volume VII, Nomor 1, Januari-Juni 2019 
Inovasi dalam sastra terus berkembang. Hal ini disebabkan sastra merupakan hasil penjumlahan atau ketegangan antara konvensi dan inovasi (Teeuw, 1980). Jika konvensi terlalu besar, sastra bersifat konvensional. Namun, kalau konvensi itu dikalahkan oleh inovasi, sastra dapat bersifat inkonvensional.

Dari dua masalah di atas, sastra semakin mengembangkan sayapnya dari yang bersifat tekstual hingga yang bersifat visual. Cerpen, novel, dan drama sekarang sudah dapat ditonton dalam bentuk film. Buku teori sastra masa kini, An Introduction to Literary Studies (1998) yang ditulis oleh seorang profesor bahasa Inggris pada Studi Amerika, Universitas Innsbruck, bernama Mario Klarer, secara khusus memasukkan genre film sebagai karya sastra. Dalam buku itu, Klarer juga membahas secara padat ihwal fiksi (fiction), puisi (poetry), drama, dan film. Pendapat Klarer mengenai film sebagai karya sastra dikutip berikut ini.

At the end of the twentieth century, it is impossible to neglect film as a semi-textual genre both influenced by and exerting influence on literature and literary critism. Film is predetermined by literary techniques, conversely, literary practice developed particular features under the impact of film. Many of the dramatic forms in the twentieth century, for example, have evolved in interaction with film, whose means of photographic depiction far surpass the means of realistic portrayal in the theater.

Film's idiosyncratic of presentation-such as camera angle, editing, montage, slow and fast motion-often parallel features of literary texts or can be explained within a textual framework (Klarer, 1998:57).

Menurut Mario Klarer, sebagaimana terdapat dalam kutipan di atas, film termasuk karya sastra dan segala macam mode presentasi film sesuai dengan fitur-fitur teks sastra dan dapat pula dijelaskan dalam kerangka tekstual. Dengan demikian, film adalah pergerakan kontemporer dari mode sastra tekstual ke mode sastra visual.

Karya sastra tidak terlepas dari eksistensi manusia. Tokoh-tokoh yang menjadi subjek atau pelaku dalam penceritaan akan mencerminkan karakter individu atau karakter sosial tertentu. Artinya, jika karya sastra tersebut berasal dari daerah bagian timur Indonesia, perwujudan eksistensi manusia tidak akan terlepas dari kebiasaan atau keadaan nyata masyarakat di sana.

Manusia, dengan eksistensi dan segala pengetahuan yang dimiliki, memungkinkan dapat beradaptasi dengan lingkungannya. Van der Weij (1988: 39) mengatakan bahwa manusia merupakan ciptaan Tuhan yang ada di muka bumi dan merupakan satu-satunya makhluk yang memiliki kemampuan berfikir dan merefleksikan segala sesuatu yang ada, termasuk diri dan keberadaannya di dunia. Kemampuan itulah yang membedakan manusia dengan makhluk lain, seperti binatang.

Karya sastra mempunyai dua aspek penting, yakni isi dan bentuk. Isi berupa pengalaman hidup manusia, sedangkan bentuk berupa cara penilaian, yaitu cara sastrawan memanfaatkan bahasa yang indah untuk mewadahi isinya (Semi, 1989: 8). Sementara itu, Pradopo (2003: 113) berpendapat bahwa karya sastra diciptakan oleh pengarang dengan tidak terlepas dari masyarakat dan budayanya. Sering kali sastrawan menonjolkan kekayaan budaya masyarakat, suku bangsa, atau bangsanya.

Hal yang sama terdapat dalam karya film. Sutradara film di Indonesia selalu menonjolkan eksistensi sosial budaya masyarakat dalam setiap karya mereka. Sebagai media hiburan dan wadah luapan ekspresi, film juga merupakan sarana pemaparan atas realitas sosial yang terjadi di kehidupan nyata. Secara visual film dapat menampilkan keadaan yang sangat mirip dengan yang sesungguhnya yang sedang terjadi di tengah-tengah masyarakat (Dila, 2017: 78).

Pada dasarnya antara sastra dan masyarakat terdapat hubungan yang hakiki. Menurut Ratna (2004: 60), hubungan itu terjadi disebabkan oleh (a) karya sastra diciptakan oleh pengarang; (b) pengarang itu sendiri adalah anggota masyarakat; (c) pengarang memanfaatkan kekayaan yang ada dalam masyarakat; dan (d) hasil karya itu dapat dimanfaatkan kembali oleh masyarakat. 
Sastra tidak lahir dalam situasi kekosongan eksistensi manusia. Eksistensi menampakkan suatu keadaan masyarakat yang telah memiliki tradisi, adat istiadat, konvensi, keyakinan, pandangan hidup, cara hidup, cara berpikir, pandangan tentang astetika, dan lain sebagainya. Sastra dapat dipandang sebagai bagian integral dari kehidupan sosial budaya masyarakat yang melahirkannya. Selain itu, sastra muncul karena masyarakat menginginkan legitimasi kehidupan sosial budayanya, tepatnya legitimasi eksistensi kehidupannya. Sebagai disiplin yang berbeda, sastra dan sosial budaya memiliki objek yang sama, yakni manusia dalam masyarakat, manusia sebagai fakta sosial, manusia sebagai makhluk kultural.

Sementara itu, dalam penelitian ini, film "Aisyah Biarkan Kami Bersaudara" karya Herwin Novianto menjadi objek karena memiliki gambaran eksistensi manusia yang menyuguhkan cerita tentang persaudaraan (toleransi antarumat beragama) dan pendidikan. Film "Aisyah Biarkan Kami Bersaudara" menjalankan fungsinya sebagai cermin sosial dengan tokoh Aisyah dan anakanak Nusa Tenggara Timur yang menjadi refleksi agar negeri ini tidak mudah terbelah atau terprovokasi.

Film "Aisyah Biarkan Kami Bersaudara" memaparkan keadaan secara realistis bagaimana wajah pendidikan Indonesia di daerah terpencil Indonesia serta perjuangan seorang guru yang menunjukkan jiwa nasionalis, survivor, dan pengabdian yang totalitas dengan tidak memedulikan masalah ras dan agama meskipun masalah ras dan agama tersebut masih menjadi permasalahan di masyarakat.

Herwin Novianto adalah sutradara film yang andal. Kemampuannya di dunia perfilman telah memberikan kontribusi yang besar bagi kemajuan perfilman yang berkualitas di Indonesia. Film "Aisyah Biarkan Kami Bersaudara" merupakan salah satu film yang menggambarkan realita kehidupan sosial masyarakat daerah terpencil di pedalaman Nusa Tenggara Timur. Film yang diproduksi pada 2016 itu digarap oleh rumah produksi film One Productions dan diangkat dari kisah nyata seorang wanita muslim yang menjadi guru di sebuah desa terpencil: Dusun Derok, Kecamatan Biboki Anleu, Kabupaten Timur Tengah Utara, Provinsi Nusa Tenggara Timur, yang penduduknya mayoritas beragama Kristen.

Film "Aisyah Biarkan Kami Bersaudara" berkisah tentang seorang sarjana pendidikan dari desa kecil di daerah Atambua, Nusa Tenggara Timur, bernama Aisyah. Seperti kebanyakan sarjana pendidikan lainnya, Aisyah bercita-cita dan ingin mengabdikan hidupnya untuk menjadi seorang guru yang bersahaja dan mampu memperbaiki kualitas pendidikan di Indonesia.

Penilitian ini bertujuan untuk mendeskripsikan eksistensi manusia dalam film "Aisyah Biarkan Kami Bersaudara" karya Herwin Novianto.

Eksistensi manusia berkaitan erat dengan filsafat sastra. Filsafat sastra adalah filsafat yang menganalisis nilai-nilai kehidupan manusia yang dijabarkan seorang sastrawan dalam karya sastranya; filsafat sastra adalah filsafat yang menganalisis karya sastra dengan latar belakang bahwa sastra merupakan bagian dari kehidupan manusia, sastra sebagai pranata sosial yang menggambarkan keadaan masyarakat dan kehidupan budaya pada masa tertentu, dan sastra sebagai refleksi kehidupan manusia dengan Tuhan; filsafat sastra merupakan wadah falsafah kehidupan yang menempatkan nilai kemanusiaan dengan semestinya, terutama di tengah-tengah kehidupan kemajuan sains dan teknologi (Djojosuroto, 2007: 54). Berdasarkan uraian di atas, dapat dipahami bahwa filsafat sastra adalah filsafat yang mengupas hakikat nilainilai kehidupan manusia yang terkandung dalam karya sastra. Kehidupan manusia tersebut meliputi hubungan manusia dengan manusia dan hubungan manusia dengan alam (hubungan horizontal) serta hubungan manusia dengan Tuhan (hubungan vertikal). Hubunganhubungan dalam kehidupan manusia tersebut merupakan wujud eksistensi.

Eksistensi berasal dari bahasa Inggris, yaitu excitence yang berarti 'keluar' dan sistere yang berarti 'muncul atau timbul'. Secara terminologis, eksistensi mengandung 
beberapa pengertian: (1) apa yang ada; (2) apa yang memiliki aktualitas (ada); dan (3) segala sesuatu yang di dalam menekankan bahwa sesuatu itu ada (Bagus, 2005: 183).

Eksistensi berarti keberadaan. Cara manusia berada di dunia berbeda dengan cara benda-benda. Benda-benda tidak sadar akan keberadaannya, tidak ada hubungan antara benda yang satu dengan benda yang lainnya, meskipun saling berdampingan. Keberadaan manusia di antara benda-benda itulah yang membuat manusia berarti. Cara berada bendabenda berbeda dengan cara berada manusia.

Dalam filsafat eksistensialisme, benda hanya sebatas "berada", sedangkan manusia lebih dari apa yang dikatakan "berada". Manusia tidak sebatas ada, tetapi "bereksistensi". Bereksistensi itulah yang menunjukkan bahwa manusia sadar akan keberadaannya di dunia, berada di dunia, dan mengalami keberadaannya berada di dunia. Manusia menghadapi dunia, mengerti apa yang dihadapinya, dan mengerti akan arti hidupnya. Artinya, manusia adalah subjek yang menyadari, yang sadar akan keberadaan dirinya dan barang-barang atau benda yang disadarinya adalah objek (Tafsir, 2006: 218219).

Eksistensi biasanya dijadikan sebagai acuan pembuktian diri bahwa kegiatan atau pekerjaan yang dilakukan seseorang dapat berguna dan mendapat nilai yang baik di mata orang lain. Selain itu, eksistensi juga dianggap sebagai sebuah istilah yang bisa diapresiasi kepada seseorang yang sudah banyak memberi pengaruh positif kepada orang lain.

Adapun tahap-tahap eksistensi manusia adalah sebagai berikut.

1. Tahap estetis, yakni tahap yang orientasi hidup manusia sepenuhnya diarahkan untuk mendapatkan kesenangan. Pada tahap ini manusia dikuasai oleh nalurinaluri seksual oleh prinsip-prinsip kesenangan yang hedonistik dan biasanya bertindak menurut suasana hati.

2. Tahap etis, yakni mengubah pola hidup yang semula estetis menjadi etis. Ada semacam "pertobatan" yang setiap individu mulai menerima dan menghayati nilai-nilai kemanusiaan yang dipilihnya secara bebas.

3. Tahap religius, yakni, keotentikan hidup manusia sebagai subjek baru akan tercapai seandainya individu dengan mata tertutup lompat dan meleburkan diri ke dalam realitas Tuhan. Lompatan dari tahap etis ke tahap religius jauh lebih sulit daripada lompatan dari tahap estetis ke tahap etis.

Menurut Abidin (2007: 18-28), eksistensi dalam kehidupan manusia, antara lain, berupa (1) proses dinamis yang terjadi pada diri manusia; (2) pemberian makna; (3) esensi; (4) keautentik dan ketidakautentik; (5) kematian; (6) kecemasan; (7) kehendak bebas; (8) waktu; (9) ruang; (10) tubuh; (11) diri sendiri; (12) pilihan; dan (13) rasa bersalah.

Titik sentral persoalan dalam gerakan eksistensialisme adalah berbagai hal yang berubungan dengan eksistensi manusia. Berkaitan dengan hal itu, para tokoh eksistensialisme telah mengembangkan dan menguraikan berbagai pandangan menyangkut keberadaan serta kondisi-kondisi atau ciri-ciri fundamental yang ada pada manusia.

Menurut Koeswara (2002: 9), pandanganpandangan tersebut telah diterima dan disepakati secara luas untuk menjadi titik tolak atau tumpuan pikiran. Tidak saja bagi pikiran filosofis para eksistensialis, tetapi juga manjadi titik tolak bagi pemikir dan kegiatan praktis para ahli psikologis eksistensial.

Konsep eksistensi manusia tentang kebersamaan adalah suatu konsep filsafat yang sangat umum dan telah dikenal sejak manusia mengenal filsafat yang muncul sejak manusia itu sendiri menjalani kehidupan bersama. Para eksistensialis percaya bahwa kebersamaan atau hidup dengan sesama bagi manusia bukan semata-mata merupakan kebetulan atau hanya suatu realistis, melainkan merupakan sesuatu yang seharusnya ada sebab kebersamaan adalah ciri yang esensial dari keberadaan manusia. Hubungan cinta yang sungguhsungguh dijalani oleh dua pihak yang saling membuka diri, saling percaya, dan saling terlibat sambil memelihara partner cinta sebagai pribadi atau subjek (Koeswara, 2002: $15)$. 
Filsafat personalitis yang memandang individualitas manusia sebagai realitas dasar, eksistensialisme memandang kesepian sebagai kemungkinan manusia yang selalu ada atau bisa dialami dan tidak akan pernah terhapus. Para eksistensialis percaya bahwa kesepian bersumber pada kekosongan jiwa dan kesepian itu sendiri dialami individu-individu dengan berbagai bentuk perasaan yang mengikutinya, seperti rasa jenuh, takut, dan gelisah (Koeswara, 2002: 18).

Apresiasi mempunyai arti pengamatan, penilaian, dan penghargaan ataupun pengenalan terhadap suatu karya seni. Mengapresiasi mengandung sejumlah pengertian yang tidak dapat dipisahkan satu sama lain. Dalam hubungan dengan film, apresiasi juga mengandung pengertian memahami, menikmati, dan menghargai (Sumarno, 1996).

Ada tiga tahapan dalam apresiasi film, yakni pemahaman, penikmatan, dan penghargaan. Pemahaman berkaitan dengan keterlibatan emosional dan pikiran. Penonton memahami masalah, ide, ataupun gagasan, serta merasakan perasaan-perasaan dan dapat membayangkan dunia rekaan yang ingin diciptakan. Penikmatan berkaitan dengan keadaan penonton yang dalam memahami dan menghargai penguasaan pembuat film terhadap cara-cara penyajian pengalaman hingga dicapai tingkat penghayatan yang intens. Tidak seorang pun bisa menikmati karya film atau bahkan memahaminya, sampai seseorang mengerti bahasanya. Oleh karena itu, unsur-unsur film harus diselami. Sementara itu, penghargaan berkaitan dengan tahap ketika penonton memasalahkan dan menemukan hubungan pengalaman yang ia dapat dari karya film dengan pengalaman kehidupan nyata yang dihadapi, pertemuan dengan jiwa atau roh film.

\section{Metode Penelitian}

\subsection{Jenis Penelitian dan Pendekatan}

Penelitian ini adalah penelitian deskriptif kualitatif dengan menggunakan pendekatan filsafat sastra. Jenis penelitian deskriptif kualitatif merupakan salah satu prosedur penelitian yang menghasilkan data deskriptif berupa ucapan atau tulisan dan perilaku orangorang yang diamati (Bodgan dan Taylor dalam Moleong, 2007).

Sementara itu, pendekatan filsafat sastra digunakan untuk mengupas hakikat nilai-nilai kehidupan manusia yang terkandung dalam karya sastra.

\subsection{Metode dan Teknik Pengumpulan Data}

Metode yang digunakan dalam penelitian ini adalah metode audio visual, yakni dengan melihat dan mendengar suatu objek dari gambar dan suara. Sementara itu, teknik pengumpulan data menggunakan teknik simak. Teknik simak dilakukan oleh peneliti dengan menyimak dan melihat secara teliti keseluruhan film "Aisyah Biarkan Kami Bersaudara" karya Herwin Novianto yang berupa dialog dan gambar-gambar yang mencerminkan eksistensi manusia dalam film "Aisyah Biarkan Kami Bersaudara" karya Herwin Novianto.

\subsection{Sumber dan Jenis Data}

Sumber data dalam penelitian ini adalah film "Aisyah Biarkan Kami Bersaudara" karya Herwin Novianto. Jenis data dalam penelitian ini adalah dialog dan gambar yang berupa kalimat dan adegan yang menggambarkan eksistensi manusia dalam film "Aisyah Biarkan Kami Bersaudara" karya Herwin Novianto.

\subsection{Teknik Analisis Data}

Analisis data dalam penelitian ini dilakukan dengan tahapan sebagai berikut.

1. Pengidentifikasian data, yakni mengidentifikasi eksistensi manusia melalui kalimat dan adegan antartokoh dalam film "Aisyah Biarkan Kami Bersaudara" karya Herwin Novianto.

2. Pengklasifikasian data, yakni mengklasifikasi kalimat dan adegan yang mencerminkan eksistensi manusia dalam film "Aisyah Biarkan Kami Bersaudara" karya Herwin Novianto.

3. Penganalisisan data, yakni semua data yang telah diklasifikasi dianalisis dengan mendeskripsikan secara mendetail 
permasalahan yang ada dalam penelitian ini berupa eksistensi manusia dalam film film "Aisyah Biarkan Kami Bersaudara" karya Herwin Novianto.

\section{Pembahasan}

Pembahasan dalam penelitian ini berupa pendeskripsian eksistensi manusia dalam film "Aisyah Biarkan Kami Bersaudara" yang menjadi fokus masalah.

Film "Aisyah Biarkan Kami Bersaudara" karya Herwin Novianto sarat dengan gambaran eksistensi manusia dalam lingkungan masyarakat. Pengarang film memandang bahwa pendeskripsian kehidupan masyarakat yang mayoritas Kristiani menerima kedatangan minoritas (Islam) dalam keseharian mereka patut didokumentasikan.

Gambaran kehidupan sosial, budaya, dan kemasyarakatan masyarakat di bagian daerah terpencil Nusa Tenggara Timur terangkum dengan apik dalam film "Aisyah Biarkan Kami Bersaudara". Dalam mendeskripsikan eksistensi manusia, penulis menggunakan teori konsep eksistensi manusia Koeswara yang meliputi empat jenis, yakni kebersamaan dan cinta, pertentangan, keterasingan dan kesepian, serta kematian.

Adapun eksistensi manusia dalam film "Aisyah Biarkan Kami Bersaudara" karya Herwin Novianto yang didapat ada tiga jenis, yakni kebersamaan dan cinta, pertentangan, keterasingan dan kesepian. Berikut pembahasannya.

\subsection{Konsep Kebersamaan dan Cinta}

Konsep kebersamaan dan cinta adalah sebuah gambaran keadaan manusia dalam sebuah hubungan yang positif. Dalam film "Aisyah Biarkan Kami Bersaudara" karya Herwin Novianto terdapat beberapa konsep kebersamaan dan cinta yang mengapikkan film tersebut. Berikut pembahasannya.

\section{Tabel 1}

Konsep Kebersamaan dan Cinta

\begin{tabular}{|l|l|}
\hline No. & $\begin{array}{c}\text { Konsep kebersamaan dan cinta dalam } \\
\text { film "Aisyah Biarkan Kami } \\
\text { Bersaudara" }\end{array}$ \\
\hline 1. & Keakraban \\
\hline 2. & Saling membantu dan kerja sama \\
\hline 3. & Menasehati \\
\hline
\end{tabular}

\begin{tabular}{|l|l|}
\hline 4. & $\begin{array}{l}\text { Rasa saling menghormati dan } \\
\text { menghargai }\end{array}$ \\
\hline 5. & Perhatian \\
\hline 6. & Tanggung Jawab \\
\hline 7. & Keterbukaan \\
\hline 8. & Rasa Iba \\
\hline 9. & Tepa salira \\
\hline 10. & Berkeyakinan \\
\hline 11. & Berkelakar \\
\hline
\end{tabular}

\subsubsection{Keakraban}

Keakraban adalah kedekatan hubungan yang lahir dari sifat sosial dalam masyarakat. Keakraban yang tergambar dalam film "Aisyah Biarkan Kami Bersaudara" karya Herwin Novianto terlihat pada tokoh Aisyah saat memosisikan keakrabannya kepada semua orang, misalnya kepada ibunya, tetangga, sahabat, masyarakat di tempatnya mengajar. Keakraban merupakan bagian eksistensi manusia sebagai makhluk sosial.

Berikut ini contoh data dialog dalam film "Aisyah Biarkan Kami Bersaudara" yang menggambarkan kebersamaan dan cinta.

(1) Dialog Aisyah dengan tetangga

Aisyah : Pak, pagi Pak!

Tetangga 1 : Pagi Neng!

Tetangga 2 : Neng, tadi mama' nyariin Neng

Aisyah : O....gitu! Pak Dadang, Pak, nanti ba'da magrib jangan lupa datang ke sini ya

Pak Dadang : Insya Allah, Neng!

Aisyah : Matur nuwun Bapak!

(2) Dialog Aisyah dengan siswanya

Siswa 2 : Ibu guru dari Jawa-kah?

Aisyah : Iya sayang, Ibu dari Jawa Barat!

Siswa 3 : Di Jawa Barat, semua orang anggap Islam kayak Ibu?

Aisyah : Ngga juga, Thomas. Jadi, di Jawa Barat itu ada yang agamanya sama kayak kalian semua, Katholik, tapi ada juga yang Islam, tapi memang sebagian besar agamanya itu kebanyakan yang Islam.

Dua contoh percakapan di atas menggambarkan eksistensi manusia dalam hubungan keakraban antarsesama. Contoh (1) memperlihatkan keakraban Aisyah dengan tetangganya di Jawa Barat. Keakraban tampak ketika Aisyah saling menyapa dengan para 
warga saat berpapasan di jalan. Keakraban juga terlihat pada contoh (2), saat Aisyah membaur/mengakrabkan diri bersama para siswa tempatnya mengajar di Desa Atambua, Aisyah memosisikan dirinya untuk lebih aktif memberikan stimulus kepada para siswa. Hal itu dilakukan karena Aisyah melihat para siswa terlihat takut kepada orang asing, apalagi kepada penganut agama lain, yang berbeda dengan mereka.

\subsubsection{Saling Membantu/Kerja Sama}

Saling membantu adalah kegiatan timbal balik yang lahir secara rela dan ikhlas dalam kelompok masyarakat. Saling membantu yang tergambar dalam film "Aisyah Biarkan Kami Bersaudara" karya Herwin Novianto terlihat pada tokoh Aisyah dan tokoh-tokoh lain yang saling membantu dalam sebuah pekerjaan dan sumbangan pemikiran. Saling membantu merupakan bagian eksistensi manusia sebagai makhluk sosial.

Berikut ini contoh data narasi saling membantu dalam film "Aisyah Biarkan Kami Bersaudara".

(3) Aisyah bersama warga Dusun Derok membuat penampungan air bersih

Ketika mengetahui para siswa banyak yang tidak masuk sekolah akibat diare karena Dusun Derok dilanda musim kemarau sehingga persediaan air bersih semakin kurang, Aisyah tergerak hatinya untuk membuat penampungan air bersih. Aisyah bersama para siswa dan Pak Pedro pergi berlanja peralatan yang diperlukan dan bersama-sama warga membuat alat penampungan air bersih.

Ilustrasi contoh narasi film $\mathrm{di}$ atas menggambarkan eksistensi manusia dalam hubungan kerja sama antarsesama. Kepedulian Aisyah muncul karena warga Dusun Derok mengalami kekeringan akibat kemarau panjang yang berimbas pada kurangnya persediaan air bersih. Sementara itu, pengetahuan warga dusun tentang cara pembuatan penyaring air bersih masih sangat minim.

\subsubsection{Menasihati}

Menasihati adalah suatu anjuran, peringatan, ataupun teguran yang baik kepada seseorang atau kelompok. Menasihati yang tergambar dalam film "Aisyah Biarkan Kami Bersaudara" karya Herwin Novianto terlihat pada tokoh Aisyah dan tokoh-tokoh lain yang saling memberi teguran, masukan, dan anjuran yang positif. Menasihati merupakan bagian eksistensi manusia sebagai makhluk sosial.

Berikut ini contoh data menasihati dalam film “Aisyah Biarkan Kami Bersaudara”.

(4) Aisyah menasehati para siswa tentang kerukunan beragama

Aisyah: Jadi, di Indonesia itubanyak sekali agamanya, walaupun agamanya berbeda, semuanya berdampingan dengan damai, dengan rukun karena penuh cinta, penuh kasih.

Siswa 1: Nah, Lordis bilang Islam itu musuh Kristen, dong suka perang.

Aisyah : Ya... memang suka ada yang berperang, tapi setiap agama, semua agama tidak pernah mengajarkan untuk penganut yang satu berperang atau bermusuhan dengan penganut lainnya.

Contoh (4) di atas menggambarkan eksistensi manusia dalam memberikan anjuran atau nasihat kepada sesama. Kepedulian Aisyah muncul karena warga Dusun Derok, khususnya para siswa, memiliki pemikiran yang negatif tentang agama Islam. Para siswa tersugesti oleh pemikiran seorang temannya yang mengatakan bahwa Islam itu musuh Kristen dan Islam itu agama yang suka berperang. Dengan kemampuannya sebagai seorang pendidik, Aisyah mengarahkan pola pikir para siswa ke arah yang lebih positif, yakni dengan memperkenalkan pentingnya saling menghormati dan menghargai dalam kerukunan beragama, ajaran-ajaran yang telah diajarkan dalam setiap agama.

\subsubsection{Rasa Saling Menghormati dan Menghargai}

Rasa saling menghormati dan menghargai adalah sikap timbal balik dari sekelompok orang yang saling memahami dan memberikan toleransi. Rasa saling menghormati dan 
menghargai yang tergambar dalam film "Aisyah Biarkan Kami Bersaudara" karya Herwin Novianto terlihat pada tokoh Aisyah dan tokoh-tokoh lain yang saling toleransi terhadap keyakinan mereka masing-masing. Rasa saling menghormati dan menghargai merupakan bagian eksistensi manusia sebagai makhluk sosial.

Berikut ini contoh data dialog dalam film "Aisyah Biarkan Kami Bersaudara" yang menggambarkan rasa saling menghormati dan menghargai.

(5) Siku, Pedro, dan Kepala Dusun menghormati dan menghargai keyakinan Aisyah dengan memberikan makanan yang halal.

Siku : Ibu guru Aisyah agama dia Islam bukan suster

Pedro : Siapa bilang suster?

Siku : Tadi Bapak Kepala Dusun bilang dia suster. Pingsan sudah dia

K. Dusun : Katong tunggu Ibu guru bangun lalu katong makan bersama.

Siku : Tapi katong kasi makan Ibu apa? Orang Islam sunde makan daging babi na! A... katong kasi makan Ibu apa! (menunju ke dapur membuatkan mie instan untuk tokoh Aisyah)

Contoh (5) di atas menggambarkan eksistensi manusia dalam menghormati dan menghargai keyakinan sesama. Siku, Pedro, dan Kepala Dusun serta warga memperlihatkan rasa hormat mereka terhadap keyakinan yang dianut oleh Aisyah. Karena tidak mengetahui keyakinan Aisyah, tanpa sengaja warga menghidangkan daging babi. Namun, setelah mereka mengetahui agama Aisyah, Siku langsung bergegas membuatkan mi instan untuk Aisyah.

Film "Aisyah Biarkan Kami Bersaudara" mendeskripsikan berbagai rasa menghormati dan menghargai warga kepada Aisyah. Warga memperbolehkan tokoh Aisyah untuk pulang lebaran di kampungnya. Begitu pula Aisyah, bersama para siswa ia ikut membuat pohon natal untuk menyambut hari raya natal.

\subsubsection{Perhatian}

Perhatian adalah pemusatan psikis salah satu aspek psikologi yang tertuju pada suatu objek yang datang dari dalam dan luar individu. Perhatian yang tergambar dalam film "Aisyah Biarkan Kami Bersaudara" karya Herwin Novianto terlihat pada tokoh Aisyah dan tokoh-tokoh lain yang berupa tingkah laku dan rangsangan atau motivasi. Perhatian merupakan bagian eksistensi manusia sebagai makhluk sosial.

Berikut ini contoh data dialog dalam film "Aisyah Biarkan Kami Bersaudara" yang mempertlihatkan adanya perhatian.

(6) Siku merasa kasihan terhadap keadaan Aisyah yang terlihat lemas.

Aisyah : Siku, ada soal yang setengah mati to?

Siku : Sunde Ibu, beta su habis dari tadi

Aisyah : E... kenapa belum pulang?"

Siku : Beta mau pulang deng Ibu, kasian kalo Ibu pulang sendiri.

Contoh (6) di atas menggambarkan eksistensi manusia dalam memberikan perhatian kepada 57esame. Siku memperlihatkan rasa kasihannya kepada Aisyah yang sejak awal terlihat kurang sehat. Siku menawari tokoh Aisyah untuk pulang bersama dari sekolah.

Film "Aisyah Biarkan Kami Bersaudara" mendeskripsikan berbagai rasa perhatian, baik warga kepada Aisyah maupun Aisyah kepada warga. Saat Aisyah sakit, misalnya, Siku membuatkan sarapan untuk Aisyah. Warga juga memberikan sumbangan kepada Aisyah agar bisa pulang kampung.

\subsubsection{Tanggung jawab}

Tanggung jawab adalah kesadaran manusia akan tingkah laku atau perbuatan yang disengaja maupun tidak disengaja. Tanggung jawab merupakan bagian eksistensi manusia sebagai makhluk sosial.

Berikut ini contoh data dialog dalam film "Aisyah Biarkan Kami Bersaudara" yang menggambarkan adanya rasa tanggung jawab. 
(7) Aisyah bertanggung jawab atas tugasnya untuk mengabdikan diri pada salah satu sekolah terpencil di Dusun Derok.

Yohanes : Mohon maaf Ibu, untuk sementara kami belum bisa menyediakan kendaraan untuk Ibu. Jadi, sementara Ibu berjalan kaki dari rumah ke sekolah, demikian juga sebaliknya.

Aisyah : Gak apa-apa itu Pak, itu mah biasa untuk saya.

Contoh (7) di atas menggambarkan eksistensi manusia dalam menjalankan tanggung jawab pekerjaan. Aisyah memperlihatkan rasa tanggung jawabnya dan kecintaannya terhadap pekerjaaan. Aisyah rela berjalan kaki sejauh sepuluh kilo dari rumah ke sekolah demi pengabdiannya.

Film "Aisyah Biarkan Kami Bersaudara" mendeskripsikan berbagai rasa tanggung jawab warga kepada Aisyah begitu pula Aisyah kepada warga seperti saat Pedro merasa bertanggung jawab untuk menjemput dan selalu mendampingi Aisyah selama berada di Dusun Derok serta tanggung jawab Kepala Dusun untuk menghormati Aisyah saat berada di kampungnya.

\subsubsection{Keterbukaan}

Keterbukaan adalah keadaan yang memungkinkan ketersediaan informasi yang dapat diberikan dan didapat oleh masyarakat luas. Keterbukaan merupakan bagian eksistensi manusia sebagai makhluk sosial.

Film "Aisyah Biarkan Kami Bersaudara" mendeskripsikan berbagai sikap keterbukaan informasi, ilmu, dan pengalaman, baik warga kepada Aisyah maupun Aisyah kepada warga. Hal ini terlihat saat warga menjelaskan kepada Aisyah tentang keadaan kampung mereka baik kondisi alam, kondisi masyarakat yang masih kurang paham masalah ajaran Islam. Aisyah juga membagikan ilmunya kepada para siswa atau para warga, seperti tentang pentingnya menghargai orang yang berbeda agama dan mengenalkan ilmu sains dengan membuat penyaringan air bersih di Dusun Derok.

\subsubsection{Rasa Iba}

Rasa iba adalah bentuk rasa kasihan dengan apa yang dirasakan oleh orang lain. Rasa iba merupakan bagian eksistensi manusia sebagai makhluk sosial.

Film "Aisyah Biarkan Kami Bersaudara" mendeskripsikan berbagai sikap rasa iba, baik warga kepada Aisyah maupun Aisyah kepada warga. Rasa iba yang ditampakkan warga kapada Aisyah terjadi pada saat Aisyah ingin pulang kampung untuk merayakan lebaran Idulfitri. Karena biaya untuk pulang tidak cukup, warga memberikan sumbangan (berupa uang) untuk Aisyah.

Begitu pula Aisyah. Ia sangat iba terhadap keadaan psikologi Lordis yang selalu dihasut oleh pamannya untuk membenci Aisyah karena beragama Islam. Rasa tertekan Lordis itu membuat Aisyah ingin menolong Lordis agar keluar dari tekanan sang paman.

\subsubsection{Tepa Salira}

Tepa salira adalah suatu sikap yang dapat merasakan (menjaga) perasaan (bentuk pikiran) orang lain sehingga tidak menyinggung orang tersebut. Tepa salira merupakan bagian eksistensi manusia sebagai makhluk sosial.

Film "Aisyah Biarkan Kami Bersaudara" mendeskripsikan berbagai sikap tepa salira itu, baik antarwarga maupun Aisyah kepada warga. Tepa salira ditampakkan oleh Pedro saat menjaga perasaan kepala dusun yang merasa salah atas ketidaktahuannya terhadap agama yang dianut Aisyah. Pedro memosisikan diri sebagai orang yang bersalah terhadap kejadian tersebut. Sikap Pedro dalam kejadian ini merupakan bagian sikap tepa salira. Pedro ingin menyelamatkan rasa malu kepala dusun di depan warga.

Begitu pun Aisyah. Ia memiliki sikap tepa salira, yakni menjaga perasaan istri kepala dusun saat Aisyah mendengar suara lengkingan anak-anak babi yang ada di pekarangan. Aisyah mencoba menutupi rasa jijiknya.

\subsubsection{Berkeyakinan}

Berkeyakinan merupakan bagian eksistensi manusia sebagai makhluk sosial. Apa pun bentuknya, seseorang atau sekelompok orang dapat dipastikan mempunyai keyakinan atau kepercayaan. 
Film "Aisyah Biarkan Kami Bersaudara” mendeskripsikan adanya keyakinan atau kepercayaan warga desa dan Aisyah. Warga desa pememluk Kristen, sedangakan Aisyah pemeluk Islam. Warga desa melakukan kegiatan-kegiatan keagamaan sesuai dengan ajaran Kristen (seperti berdoa di tempat ibadah, memasang gambar Yesus di rumah), Aisyah pun melaksanakan ibadah sesuai dengan keyakinannya, yakni Islam. Dia melaksanakan puasa ramadan dan shalat wajib.

\subsubsection{Berkelakar}

Berkelakar adalah bercakap-cakap tidak dengan sungguh-sungguh (hanya bergurau atau berolok-olok). Berkelakar merupakan bagian eksistensi manusia sebagai makhluk sosial.

Berikut ini contoh data dialog dalam film "Aisyah Biarkan Kami Bersaudara" yang memperlihatkan kelakar.

(8) Tokoh Pedro berkelakar di depan Aisyah dan para siswa.

Pedro : Baru kapan mau pigi belanja ke Atambua? Nanti gue antar

Siswa : Saya ikut, saya ikut, saya ikut (sambil bersamaan unjukjari)

Pedro : E...e...lu ikut, lu ikut, lu tinggal, belum cukup umur (menunjuk siswa yang satu)

siswa 1 : Tapi $s a$ satu kelas

Pedro : Tapi pung tinggi belum sampe.

Contoh (8) di atas menggambarkan eksistensi manusia pada saat bercanda atau berkelakar. Sikap tersebut berfungsi untuk menghibur lawan tuturnya. Pedro berkelakar kepada Aisyah dan para siswa agar menambah suasana bahagia dan riang.

Film "Aisyah Biarkan Kami Bersaudara" mendeskripsikan berbagai peristiwa candaan, seperti saat Pedro dimarahi oleh istrinya karena lupa dengan pesanan sang istri. Candaan juga terjadi pada saat Aisyah melakukan tanya jawab kepada para siswa. Karena salah menjawab pertanyaan Aisyah, para siswa justru saling menyalahkan.

\subsection{Konsep Pertentangan}

Konsep pertentangan adalah sebuah gambaran keadaan manusia dalam sebuah hubungan yang negatif, maksudnya tidak ada hubungan kecocokan dalam suatu keadaan, pendapat, dan sebagainya. Dalam film "Aisyah Biarkan Kami Bersaudara" karya Herwin Novianto terdapat beberapa konsep pertentangan yang menampilkan klimaks film tersebut. Berikut pembahasannya.

Tabel 2

Konsep Pertentangan

\begin{tabular}{|l|l|}
\hline No. & $\begin{array}{c}\text { Konsep Pertentangan dalam film } \\
\text { "Aisyah Biarkan Kami Bersaudara" }\end{array}$ \\
\hline 1. & Ketidaksetujuan \\
\hline 2. & Ketidaksepahaman \\
\hline 3. & Rasa tidak menghargai \\
\hline 4. & Keidakterimaan \\
\hline 5. & Ketidakpercayaan \\
\hline 6. & Kebencian \\
\hline
\end{tabular}

\subsubsection{Ketidaksetujuan}

Ketidaksetujuan adalah suatu sikap atau pernyataan penolakan seseorang terhadap sesuatu yang dihadapinya. Ketidaksetujuan merupakan bagian eksistensi manusia sebagai makhluk sosial.

Berikut ini contoh data dialog dalam film "Aisyah Biarkan Kami Bersaudara" yang memperlihatkan ketidaksetujuan.

(9) Ketika Ibu Aisyah tidak menyetujui kepergiannya ke Nusa Tenggara Timur.

Ibu : Di mana?

Aisyah : NTT

Ibu : NTT? Nusa Tenggara Timur? Aisyah, waktu itu mama' teh setujusetuju aja karena kamu akan ditempatkan di bagian Tenggara, tapi kalau di Nusa Tenggara Timur, jangan... so batalin ... batalin ...jauh atuh....

Contoh (9) di atas menggambarkan eksistensi manusia saat seorang ibu tidak menyetujui keinginan atau keputusan yang diambil oleh seorang anak. Aisyah akan mengabdikan diri di sekolah dasar di NTT. Namun, keinginan tersebut tidak disetujui karena Ibunya beranggapan bahwa NTT adalah tempat yang sangat jauh untuk Aisyah. Pergolakan batin dalam diri kedua tokoh 
tersebut tampak menjadi pertentangan di antara kedua tokoh tersebut.

\subsubsection{Ketidaksepahaman}

Ketidaksepahaman adalah suatu sikap atau pernyataan antara dua pikiran yang tidak sepaham dalam suatu hal. Ketidaksepahaman merupakan bagian eksistensi manusia sebagai makhluk sosial.

Berikut ini contoh data dialog dalam film "Aisyah Biarkan Kami Bersaudara" yang memperlihatkan ketidaksepahaman.

(10) Ketidaksepahaman para siswa terhadap kedatangan Aisyah yang berbeda agama dengan mereka ke Dusun Derok.

Aisyah : Kenapa semua takut sama Lordis sih? Kenapa di sini takut sama Lordis? Marselo coba berdiri, badan kamu tingginya sama kayak Lordis, iya? Pasti kamu juga pintarnya sama dengan dia, jagoan, gagah, tapi kenapa kamu harus takut Lordis Devas?

Marselo : Beta seng takut Lordis Ibu, beta takut Ibu $\mathrm{Sa}$

Aisyah : He... takut sama Ibu? Kenapa

Marselo : Beta takut, sama Lordis bilang, Ibu datang di sini buat kasi rusak katong gereja-gereja.

Contoh (10) di atas menggambarkan eksistensi manusia saat para siswa tidak mempunyai pemahaman tentang perbedaan agama. Eksistensi agama Islam pada pandangan mereka masih negatif, yakni Islam dianggap sebagai musuh dari agama yang mereka anut. Marselo terang-terangan mengatakan kepada Aisyah jika kedatangan Aisyah merupakan ancaman untuk mereka.

\subsubsection{Rasa Tidak Menghargai}

Rasa tidak menghargai adalah suatu jenis sikap sosial terhadap sesama yang tidak menjalin hubungan harmonis. Rasa tidak menghargai merupakan bagian eksistensi manusia sebagai makhluk sosial.

Film "Aisyah Biarkan Kami Bersaudara" mendeskripsikan adanya rasa tidak menghargai, antara tokoh yang satu dengan tokoh yang lain, pada Lordis. Ia tidak menghargai keberadaan Aisyah sebagai guru di sekolahnya. Rasa tidak menghargai Lordis muncul karena keyakinan Aisyah berbeda dengan keyakinan warga Dusun Derok, yakni Katholik. Lordis menghasut siswa yang lain untuk mengusir dan membenci Aisyah. Bahkan, Lordis sempat melempar Aisyah dengan batu.

\subsubsection{Ketidakterimaan}

Ketidakterimaan adalah ketidakkendalian terhadap kenyataan yang sedang dialami. Ketidakterimaan merupakan bagian eksistensi manusia sebagai makhluk sosial.

Eksistensi ketidakterimaan dalam film "Aisyah Biarkan Kami Bersaudara" tampak pada saat Lordis dan pamannya tidak menerima keberadaan Aisyah di Dusun Derok. Lordis dan pamannya sangat membenci keyakinan yang dianut Aisyah. Menurut cerita kepala dusun, kebencian Lordis terhadap agama Islam berawal dari kejadian perpecahan agama di Ambon. Kala itu Lordis bersama keluarganya berada di Ambon.

\subsubsection{Ketidakpercayaan}

Ketidakpercayaan adalah perasaan ketidakpastian atau keragu-raguan seseorang terhadap orang atau hal yang dihadapinya. Ketidakpercayaan merupakan bagian eksistensi manusia sebagai makhluk sosial.

Eksistensi ketidakpercayaan dalam film "Aisyah Biarkan Kami Bersaudara" terlihat pada saat Lordis tidak percaya dengan keberadaan Aisyah. Lordis membubarkan para siswa saat Aisyah ingin berkenalan dengan para siswa satu per satu. Semua siswa pun keluar dari ruang kelas karena termakan oleh hasutan Lordis.

\subsubsection{Kebencian}

Kebencian adalah emosi yang sangat kuat dan melambangkan ketidaksukaan, permusuhan, atau antipati kepada seseorang. Kebencian merupakan bagian eksistensi manusia sebagai makhluk sosial.

Eksistensi rasa kebencian dalam film "Aisyah Biarkan Kami Bersaudara" tampak pada saat Aisyah mendatangi rumah Lordis Defam dan bertemu dengan pamannya Lordis. Paman Lordis memarahi Aisyah dengan penuh 
kebencian karena dia berpikir kedatangan Aisyah di kampungnya akan mendatangkan masalah. Tuturan paman Lordis berikut memperlihatkan kebencian itu.

"Trus, lu tujuan apa datang ke pung kampung? Eh...jangan omong kosong kastau lu pung orang-orang yang suruh datang ke sini, jangan bikin kaco."

\subsection{Konsep Kesepian dan Keterasingan}

Konsep kesepian dan keterasingan adalah sebuah gambaran keadaan manusia dalam hal atau keadaan terasing dan sepi dari manusia lain. Dalam film "Aisyah Biarkan Kami Bersaudara" karya Herwin Novianto terdapat beberapa konsep kesepian dan keterasingan yang menampilkan nuansa sedih. Berikut pembahasannya.

Tabel 3

Konsep Kesepian dan Keterasingan

\begin{tabular}{|l|l|}
\hline No. & $\begin{array}{c}\text { Konsep Kesepian dan Keterasingan } \\
\text { dalam film "Aisyah Biarkan Kami } \\
\text { Bersaudara" }\end{array}$ \\
\hline 1. & Kesedihan \\
\hline 2. & Kegelisahan \\
\hline 3. & Kejengkelan \\
\hline 4. & Kekhawatiran \\
\hline 5. & Ketakutan \\
\hline 6. & Kebohongan \\
\hline
\end{tabular}

\subsubsection{Kesedihan}

Kesedihan adalah suatu emosi yang ditandai oleh perasaan tidak beruntung, kehilangan, dan ketidakberdayaan. Kesedihan merupakan bagian eksistensi manusia sebagai makhluk sosial.

Pendeskripsian eksistensi manusia dengan rasa sedih dalam film "Aisyah Biarkan Kami Bersaudara" tampak pada saat Lordis mengalami kecelakaan. Ia ditolong oleh Aisyah dan para siswa, dibawa ke rumah sakit. Namun, masih dalam masa perawatan, paman Lordis datang, lalu membuka infus Lordis dan memaksanya untuk keluar dari rumah sakit. Kesedihan dan ketidakberdayaan Lordis terlihat jelas karena Lordis tidak bisa melawan pamannya yang telah merawatnya selama ini.

\subsubsection{Kegelisahan}

Kegelisahan adalah keadaan psikologi dan fisiologis yang tidak tenteram dalam hati seseorang terhadap hal yang dialaminya. Kegelisahan merupakan bagian eksistensi manusia sebagai makhluk individu dan makhluk sosial.

Pendeskripsian eksistensi manusia dengan rasa gelisah dalam film "Aisyah Biarkan Kami Bersaudara" tampak pada saat Aisyah merasa gelisah terhadap keadaan keuangannya yang tidak mencukupi untuk pulang kampung saat lebaran Idulfitri.

\subsubsection{Kejengkelan}

Kejengkelan adalah perasaan kesal, dongkol terhadap sesuatu yang dialami manusia. Kejengkelan merupakan bagian eksistensi manusia sebagai makhluk sosial.

Berikut ini contoh data dialog dalam film "Aisyah Biarkan Kami Bersaudara" yang memperlihatkan kejengkelan.

(11) Kejengkelan Aisyah kepada Jaya yang akan pergi ke Aceh.

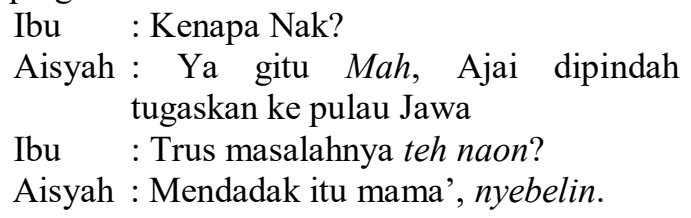

Contoh (11) di atas menggambarkan eksistensi Aisyah pada saat mengalami pergolakan batin, yakni merasa jengkel dengan sosok Ajai yang mendadak dipindahtugaskan ke luar Pulau Jawa. Pergolakan rasa jengkel yang ada pada diri Aisyah muncul karena hubungan mereka berdua belum ada kejelasan status.

\subsubsection{Kekhawatiran}

Kekhawatiran adalah sikap berpikir berlebihan atau terlalu cemas tentang suatu masalah atau situasi. Kekhawatiran merupakan bagian eksistensi manusia sebagai makhluk sosial.

Berikut ini gambar dan tuturan contoh data dalam film "Aisyah Biarkan Kami Bersaudara" yang memperlihatkan kekhawatiran. 
(12) Kekhawatiran para siswa kepada Aisyah saat akan menjaga Lordis di rumah sakit.

Aisyah : Langsung pulang sama Pak Pedro ya?

Siku : Ei... sunde bisa Ibu, katong sunde bisa kas tinggal Ibu sendiri di sini deng Lordis.

Aisyah : Kenapa? Su usah khawatir Siku, ya? Beta sunde apa-apa.

Contoh (12) di atas menggambarkan kekhawatiran para siswa terhadap Aisyah. Mereka mengkhawatirkan Aisyah berdekatan dengan Lordis karena mereka tahu bahwa Lordis sangat membenci Aisyah.

\subsubsection{Ketakutan}

Ketakutan adalah suatu tanggapan emosi terhadap ancaman bahaya atau rasa sakit. Ketakutan merupakan bagian eksistensi manusia sebagai makhluk individu dan makhluk sosial.

Berikut ini contoh data dialog dalam film "Aisyah Biarkan Kami Bersaudara" yang memperlihatkan rasa ketakutan.

(13) Siku rela berbohong kepada Aisyah dan neneknya.

Aisyah : Jadi siapa yang pukul kamu?

Siku : E ... suangge, Ibu

Aisyah : Suangge itu apa, Siku?

Siku : Manusia kuntilanak Ibu, dia bisa terbang macam burung.

Contoh (13) di atas menggambarkan ketakutan Siku untuk mengaku kepada Aisyah, Ibu Dusun, dan neneknya atas pemukulan Lordis kepadanya. Siku berbohong kepada tokoh lainnya bahwa yang memukulnya adalah setan yang biasa mereka sebut suangge. Hal ini dilakukan Siku karena dia sangat takut kepada Lordis.

\subsubsection{Kebohongan}

Kebohongan adalah bentuk pernyataan yang tidak benar, dengan niat untuk menjaga rahasia atau reputasi, perasaan, dan melindungi seseorang untuk menghindari hukuman atau menolak suatu perbuatan.

Pendeskripsian eksistensi manusia dengan kebohongan dalam film "Aisyah Biarkan Kami Bersaudara" tampak pada saat Siku membohongi para tokoh lain atas pemukulan yang dialaminya. Hal ini terlihat pada contoh data (13). Tokoh Siku menyembunyikan pelaku (Lordis) karena merasa takut nanti para tokoh lain mendatangi dan menghukum Lordis.

\section{Simpulan}

Berdasarkan penelitian yang telah dilakukan, dapat disimpulkan beberapa hal yang terkait dengan konsep eksistensi manusia dalam film "Aisyah Biarkan Kami Bersaudara" karya Herwin Novianto.

Terdapat tiga konsep eksistensi manusia dalam film "Aisyah Biarkan Kami Bersaudara" karya Herwin Novianto, yakni (1) konsep kebersamaan dan cinta; (2) konsep pertentangan; serta (3) konsep keterasingan dan kesepian.

Konsep kebersamaan dan cinta merupakan gambaran keadaan manusia dalam sebuah hubungan yang positif yang ditampakkan melalui sikap suatu individu kepada individu yang lain. Bentuk konsep kebersamaan dan cinta dalam film "Aisyah Biarkan Kami Bersaudara" karya Herwin Novianto meliputi keakraban, saling membantu/kerja sama, menasehati, rasa saling menghormati dan menghargai, perhatian, tanggung jawab, keterbukaan, rasa iba, tepa salira, berkeyakinan, dan berkelakar. Konsep pertentangan merupakan pergolakan jiwa yang dirasakan oleh seseorang baik pengaruh lingkungan, batin, maupun kelompok manusia. Bentuk konsep pertentangan dalam film "Aisyah Biarkan Kami Bersaudara" karya Herwin Novianto meliputi ketidaksetujuan, ketidaksepahaman, rasa tidak menghargai, ketidakterimaan, ketidakpercayaan, dan kebencian.

Sementara itu, konsep keterasingan dan kesepian merupakan gambaran keadaan manusia dalam keadaan terasing dan sepi dari manusia lain. Bentuk konsep pertentangan dalam film "Aisyah Biarkan Kami Bersaudara" karya Herwin Novianto meliputi kesedihan, kegelisahan, kejengkelan, kekhawatiran, ketakutan, dan kebohongan. 


\section{Daftar Pustaka}

Abidin, Zainal. (2007). Analisis Eksistensial, Sebuah Pendekatan Alternatif untuk Psikologi dan Psikiatri. Jakarta: PT Raja Grafindo.

Bagus, Lorens. (2005). Kamus Filsafat. Jakarta: Gramedia Pustaka Utama.

Dila, Putri Andini Kusumawardani. (2017). "Gambaran Eksistensi Tokoh Sandra dalam Film Deux Jours Une Nuit Karya Jean-Plerre Dardenne dan Luc Dardenne: Kajian Psikologi Eksistensial". Thesis. Universitas Brawijaya.

Djojosuroto, Kinayati. (2007). Filsafat Bahasa. Yogyakarta: Pustaka Book.

Klarer, Mario. (1998). An Introduction to Literary Studies. London: Routledge.

Koeswara. (2002). Psokologi Eksistensial Suatu Pengantar. Bandung: Rosda Offset.

Moleong, Lexi. (2007). Metodologi Penelitian Kualitatif. $\quad$ Bandung: Remaja Rosdakarya.

Pradopo, Rahmat Djoko. (2003). Prinsipprinsip Kritik Sastra. Yogyakarta: Gadjah Mada University Press.

Ratna, Nyoman Kutha. (2004). Paradigma Sosiologi Sastra. Yogyakarta: Pustaka Pelajar.

Semi, M. Atar. (1989). Kritik Sastra. Bandung: Angkasa.

Sumarno, Marseli. (1996). Dasar-dasar Apresiasi Film. Jakarta: PT Grasindo.

Tafsir, Ahmad. (2006). Filsafat Pendidikan Islami. Jakarta: PT Remaja Rosdakarya.

Teeuw, A. (1984). Sastra dan Ilmu Sastra: Pengantar Teori Sastra. Jakarta: Pustaka Jaya.

Van der Weij, P. A. (1988). Filsuf-Filsuf Besar tentang Manusia (Terj.: K. Bertens). Gramedia: Jakarta. 